\title{
The effect of highly variable topography on the spatial distribution of Aniba perutilis (Lauraceae) in the Colombian Andes
}

\author{
José C. Fagua ${ }^{1}$, Edersson Cabrera ${ }^{2} \&$ Victor H. Gonzalez ${ }^{3}$ \\ 1. Grupo de investigación en Percepción Remota, Centro de Investigación y Desarrollo en Información Geográfica- \\ CIAF, Instituto Geográfico Agustín Codazzi-IGAC, Carrera 30 No. 48-51, Bogotá D.C., Colombia; \\ camilo_fagua@yahoo.com \\ 2. Instituto de Hidrología, Meteorología y Estudios Ambientales-IDEAM-, Bogotá, Colombia; \\ edersson.cabrera@gmail.com \\ 3. Department of Biological Sciences, Southwestern Oklahoma State University, 100 Campus Drive, Weatherford, \\ Oklahoma, 73096, USA, \& Division of Entomology, Natural History Museum, 1501 Crestline Drive - Suite 140, \\ University of Kansas, Lawrence, Kansas 66045, USA; victorgonzab@gmail.com
}

Received 13-XII-2011. C Corrected 27-V-2012. Accepted 27-VI-2012.

\begin{abstract}
Topography is a factor that can significantly affect the diversity and the distribution of trees species in tropical forests. Aniba perutilis, a timber species listed as vulnerable to extinction, is widely distributed in Andean forest fragments, especially in those with highly variable topography. Based on field surveys and logistic regression analyses, we studied the population structure and the effect of highly variable topography on the spatial distribution of this tree in three protected forest fragments in the central Andes of Colombia. Individuals of $A$. perutilis were mainly found on mountain ridges and hills with gentle slopes; no individuals were found in valleys. Using a species distribution model with presence/absence data, we showed that the available habitat for A. perutilis is significantly smaller than the extension of the fragments and much smaller than the extension of the currently protected areas. Our results have important implications for the conservation of $A$. perutilis and likely for other threatened Andean tree species, which can also have locally restricted distributions due to highly variable local topography. Rev. Biol. Trop. 61 (1): 301-309. Epub 2013 March 01.
\end{abstract}

Key words: conservation biology, forest fragments, logistic regression, species distribution models, population structure.

The tropical Andes are one of the most diverse areas in the world, containing about one-sixth of all plant life in less than $1 \%$ of the world's land area (Kattan et al. 2004). This ecosystem reaches its maximum physical complexity and biological diversity in Colombia, where it is divided into three main mountain ranges: the Western, Central, and Eastern Cordilleras (Kattan et al. 2004). Because of its diversity of climates and ecosystems, that allow the production of a wide variety of food, about $70 \%$ of Colombian population ( $\sim 31$ million of people) is concentrated in the Andes, which has strongly transformed native forests during the last century. Today, it is estimated that nearly $64.5 \%$ of the native Andean forests have been deforested during the past 40 years, especially in the central Andes (Cabrera et al. 2011). Most of the remaining native forest is sparsely found in patches or relicts along the Andes, especially in areas with highly variable topography where it is difficult to establish crops and grazing pastures for cattle ranching, the principal economic activities of this region.

Topography at the local scale is a factor that significantly affects the diversity and distribution of trees species in tropical and sub tropical forests (Oliveira-Filho et al. 1994, Clark et al. 1998, Oliveira et al. 1998, Gale 2000, Harms et al. 2001, Kubota et al. 2004). Topographic changes (i.e., variation of topographic units and topography gradient) produce discontinuities in 
edaphic conditions, thus affecting the establishment of trees (Clark et al. 1998). The effects of topography on the distribution of trees at the local scale and their consequences on the landscape scale have not been evaluated in any tree species of forest fragments in the tropical Andes. Such studies are relevant to promote the conservation of threatened tree species that are currently restricted to forest fragments with highly variable topography, such as those of the Colombian Andes.

Aniba perutilis Hemsley (Lauraceae) is a good example of a tree species restricted to such Andean forest fragments that is currently listed as a species vulnerable to extinction due to habitat loss and overexploitation (PRVCAB 1994, UICN 2001, Vargas 2002). This timber species, commonly known as "comino" or "comino laurel", is greatly esteemed for high-grade furniture, interior trim, durable construction, and resistance to the attack of termites (Bernal 1994). This species is widely distributed in the Neotropical region, occurring from lowlands to mid elevations (0-2600m) from Colombia to Bolivia. The species becomes more abundant in Andean forests, and although it was one of the most common trees in the "Cordillera Central" of Colombia. Today it is rarely found (PRVCAB 1994, UICN 2001, Vargas 2002). Populations of $A$. perutilis in Colombia have been identified in three forest fragments along the Western flank of the Central Cordillera. These fragments (Bremen Forest Reserve, OtúnQuimbaya Natural National Park, and the Canyon of the Barbas River) are characterized by highly variable topography and by being surrounded by plantations of exotic trees and grazing pastures. To preserve these forest fragments, the state and federal governments of Colombia have established protected areas around them under the System of Protected Areas of Colombia (SINAP).

In this study, we sought to determine if topography could affect the distribution of $A$. perutilis inside these forest remnants. If this is the case, it would seem likely to find $A$. perutilis restricted to certain areas within the fragments, thus suggesting that the available habitat to $A$. perutilis would be significantly smaller than the extension of the fragment and much smaller than the extension of the protected area. To achieve this goal, we studied the relationship among several independent environmental variables and the probability of finding $A$. perutilis within the fragments using field data and logistic regression analyses. We then modeled the potential distribution of $A$. perutilis to estimate its available habitat using field data and Geographic Information Systems (GIS) tools.

\section{MATERIALS AND METHODS}

Study site and species: This study was conducted from June 2005 to May 2006 on three large forest relicts and the protected areas that enclose them on the Western slope of the Cordillera Central of Colombia (43- $42^{\prime}$ $\left.\mathrm{N}-75^{\circ} 32-38^{\prime} \mathrm{W}\right)$ : The Canyon of the Barbas River (CB), the Bremen Forest Reserve (BFR), and the National Natural Park Otún-Quimbaya (NNPO). These three areas are located between the departments of Risaralda and Quindío, at $1600-2000 \mathrm{~m}$ (Fig. 1), are characterized by their abrupt canyon formations, and are surrounded by plantations of exotic grasses and trees (Pinus patula, Cupressus sp. and Eucalyptus sp.). The rainy season is bimodal, with a maximum from April to May and another from October to November. The mean annual rainfall is $2817 \mathrm{~mm}$ and the mean monthly temperature is $16-24^{\circ} \mathrm{C}$. The vegetation is classified as subandean forest (sensu Cuatrecasas 1958) or premontane moist forest, bmh-PM (sensu Holdridge 1947). Numerous threatened animal species inhabit these forest fragments, such as Alouatta seniculus (Red howler monkey), Aotus lemurinus (Lemurine owl monkey), Dinomys branicki (Pacarana), Penelope perspicax (Cauca guan), Aburria aburri (Wattled guan), and Odontophorus hyperythrus (Chestnut wood-quail) (PNNC 2007). Due to the biological importance of these forest fragments, the Humboldt Institute and other Colombian 


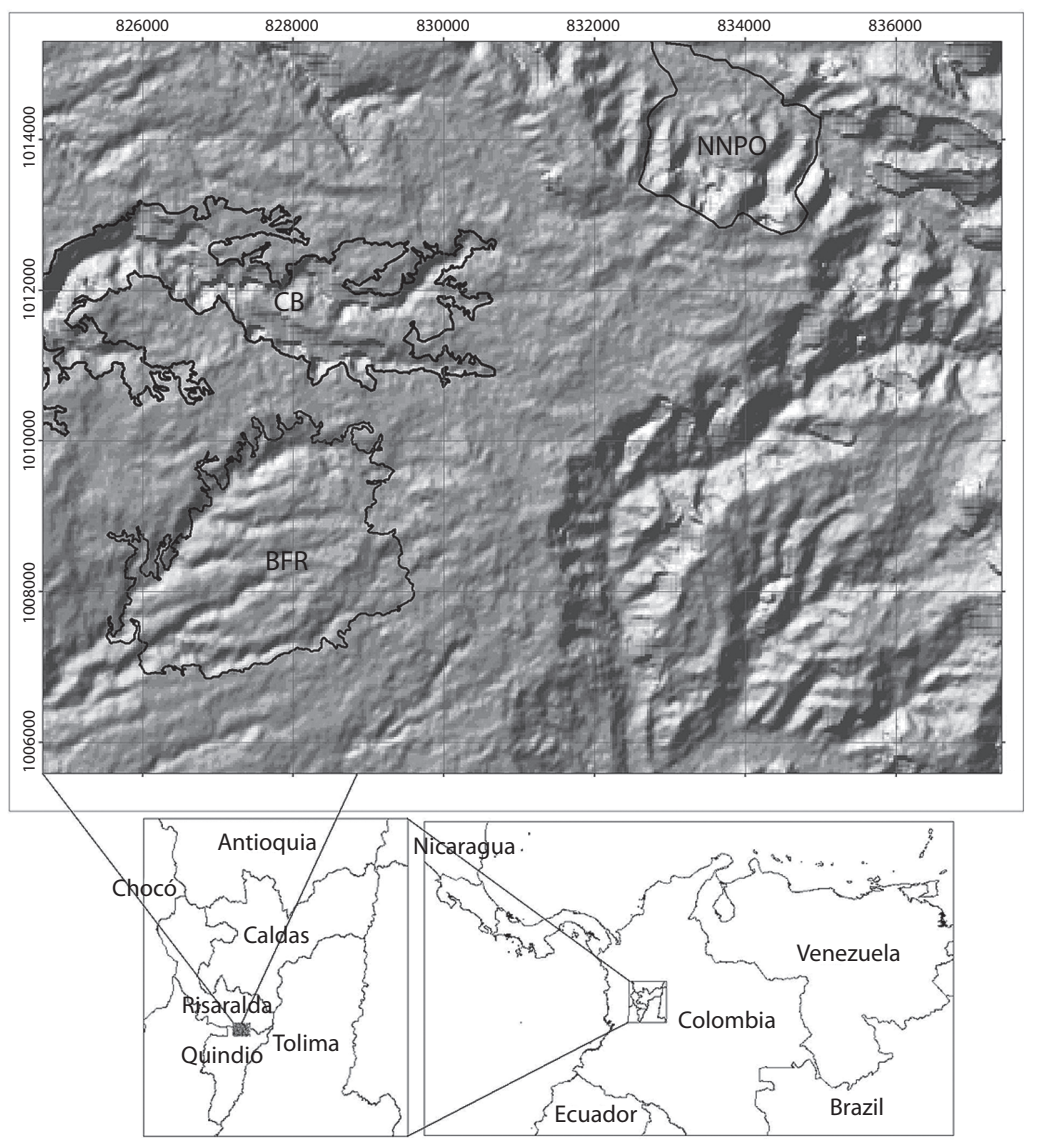

Fig. 1. Shaded relief of the study area showing the three protected areas in the central Andes of Colombia: Canyon of the Barbas River (CB), Bremen Forest Reserve (BFR), and National Natural Park Otún-Quimbaya (NNPO). Note the highly variable topography of these areas. The grid of the top map is in meters according to WGS 84 Datum and UTM projection (scale 1:10 000).

institutions are trying to develop biological corridors that connect these three fragments.

Aniba perutilis is a large, evergreen canopy tree that reaches over $30 \mathrm{~m}$ in height and $2 \mathrm{~m}$ in diameter at maturity. The leaves are simple, coriaceous, lanceolate, and are arranged alternately on the stems. The flowers are small, bisexual, and brown to reddish-brown in color. The fruit is a fleshy, oil-rich, pear-shaped drupe (PRVCAB 1994, Vargas 2002). The blooming peak occurs through the drier months and fruiting occurs through the rainy season (Alzate 1987). Seeds are primarily dispersed by Oilbirds (Steatornis caripensis) and several species of Toucans (Ramphastidae).
Preliminary GIS analysis and field methods: A map of vegetation cover types in the study area was generated using Ikonos Imagine (spatial resolution $1 \mathrm{~m}^{2}$ ); field checks were done to improve the accuracy of these maps. We identified and digitized the following vegetation types: 1) Andean forests, 2) introduced grasslands, 3) plantations of exotic trees, 4) high shrubs, 5) intermediate shrubs, 6) low shrubs, 7), isolated trees, 8) cultivated lands, 9) rivers, and 10) roads. Using the Digital Elevation Model (DEM) STRM (Shuttle Radar Topography Mission) at $30 \mathrm{~m}^{2}$ of spatial resolution, and our mapping of vegetation, we superimposed a grid of $300 \mathrm{~m}^{2}$ cells over 
these layers and chose the cells that met two criteria: i) Andean forest cover of at least $70 \%$ of cell because $A$. perutilis is a canopy tree that grows inside mature forest, and ii) gentle topographic gradient $\left(<30^{\circ}\right)$ of at least $30 \%$ within each cell because areas with such a gradient are uncommon in these forest fragments and our preliminary field data showed that $A$. perutilis is predominantly found in areas with gentle topography. We found 85 cells with these two criteria (37 in NNPO, 39 in FRB, and 9 in $\mathrm{CB}$ ).

We randomly selected 27 of the 85 cells (nine in each one of three fragments) and established a $10 \mathrm{~m}$ wide transect in each cell in the field using a GPS. The length of the transect ranged from 60 to $100 \mathrm{~m}$ due to canyon formations in the fragments. Such transects were oriented perpendicular to the topographic gradient lines and were divided every $5 \mathrm{~m}$ into $5 \times 10 \mathrm{~m}^{2}$ plots. In each plot, we recorded the topographic gradient, topographical units (valley, hillside, and ridge), and altitude. In each $5 \times 10 \mathrm{~m}^{2}$ plot, a census of all $A$. perutilis individuals taller than $35 \mathrm{~cm}$ was taken, whereas individuals shorter than $35 \mathrm{~cm}$ were taken in $1 \times 10 \mathrm{~m}^{2}$ plot nested within the $5 \times 10 \mathrm{~m}^{2}$ plot. The diameter at breast height $(\mathrm{DBH})$ and height of each individual was recorded in all plots. Based on the DBH and Sturges' (1926) equation, individuals were grouped in the following size classes: Class 1 $(0-0.4 \mathrm{~cm})$, Class $2(0.4-3 \mathrm{~cm})$, Class $3(3-6 \mathrm{~cm})$, Class $4(6-9 \mathrm{~cm})$, Class $5(9-12 \mathrm{~cm})$, Class 6 (12$15 \mathrm{~cm})$, Class $7(15-18 \mathrm{~cm})$, Class $8(18-21 \mathrm{~cm})$, Class $9(21-24 \mathrm{~cm})$, Class $10(25-40 \mathrm{~cm})$, Class $11(40-55 \mathrm{~cm})$, and Class $12(>55 \mathrm{~cm})$.

Analysis of field data: We used multiple logistic regression (MLR) to estimate the relationships between topographic gradient, topographical units (valley, hillside, and ridge), and altitude (explanatory variables) with the probability of finding $A$. perutilis in the forest fragments (response variable). MLR estimates the probability of presence, $P(y=1)$, of $A$. perutilis based on $n$ explanatory variables.

$$
P(y=1)=\frac{1}{1+\exp \left[-\left(\beta+\beta_{1} n_{1}+\beta_{2} n_{2}+\ldots .+\beta_{\mathrm{n}} n_{\mathrm{n}}\right)\right]}
$$

MLR is a special case of a generalized linear model that has suitable characteristics to analyze our data: 1) the response variable is binary (present/absent), which reduces effects of spatial autocorrelation (Lichstein et al. 2002) and pseudoreplication, 2) the explanatory variables can be numerical, categorical, binary or a mix of all them as in our case, and 3) the MLR model can be implemented into GIS to construct a map of potential distribution of the species. We applied two MLR analyses: 1) one to relate the probability of finding individuals taller than $35 \mathrm{~cm}$ in the 454 plots $\left(5 \times 10 \mathrm{~m}^{2}\right)$ and 2) the other to relate the probability of finding individuals shorter than $35 \mathrm{~cm}$ in height in the 454 nesting plots $\left(5 \times 1 \mathrm{~m}^{2}\right)$. Statistical analyses were done using Statistica 9.3 and SPSS 13.

Spatial Model of potential distribution: We constructed four raster maps corresponding to the explanatory variables mentioned before (topographic gradients, valleys, hillsides, and ridges) in forest fragments areas. Topographic gradients, valleys, and ridges rasters were obtained from STRM DEM using ArcGIS 9.3; specifically we used the following tools: Slope for topographic gradients, Arc Hydro (Version 1.0 Beta 2; Maidment 2002) for valleys, and Raster Surface for ridges. Areas which were not classified as valleys or ridges were classified as hillside because forest fragments are canyons with highly variable topography and without flat areas. Maps were projected in Magna-Sirgas Datum of Colombia, region VI (scale 1:10 000). Subsequently, we constructed a map of potential distribution of $A$. perutilis (raster of probability of finding $A$. perutilis) using a MLR model that takes into account the parameters of MLR of field data as follows:

$$
P\left(\text { Raster }_{\mathrm{y}}=1\right)=\frac{1}{1+\exp \left[-\left(\beta+\beta_{1} \text { Raster }_{\mathrm{n} 1}+\beta_{2} \text { Raster }_{\mathrm{n} 2}+\ldots .+\beta_{3} \text { Raster }_{\mathrm{n} 3}\right)\right]}
$$


Maps were projected in WGS 84 (World Geodetic System 84) Datum and UTM (Universal Transverse Mercator) projection (scale 1:10 000).

\section{RESULTS}

The explanatory variable topographic gradient was highly correlated with the probability of finding $A$. perutilis inside the forest fragments. The relationship was negative, and its magnitude was greater in individuals taller than $35 \mathrm{~cm}$ (Wald $=55.2, \mathrm{p}<0.0001$ ) than in individuals shorter than $35 \mathrm{~cm}$ (Wald $=31.8$, $\mathrm{p}<0.0001$ ) (Fig. 2); however, it was not statistically significantly different $\left(\mathrm{X}^{2}=1.4\right.$, $p=1.0$ ). The topographical units, ridge and hillside, showed a significant relationship to the probability of finding $A$. perutilis in both individuals shorter than $35 \mathrm{~cm}$ (Wald $=21.3$, $\mathrm{p}<0.0001$; Wald $=30.9, \mathrm{p}<0.0001$, respectively) and individuals taller than $35 \mathrm{~cm}$ (Wald $=43.4$, $\mathrm{p}<0.0001$; Wald $=54.2, \mathrm{p}<0.0001)$. The remaining explanatory variables (valley and altitude) did not have a significant relationship. When forest fragments are treated in the analysis as explanatory variables, we found that $\mathrm{CB}$ and NNPO have a significant relationship to the probability of finding $A$. perutilis in both, short (CB: Wald $=22.4, \mathrm{p}=0.0001$; NNPO: Wald $=40.7, p=0.0001$ ) and tall individuals (CB: Wald $=22, \mathrm{p}=0.0001$; NNPO: Wald $=24.7$, $\mathrm{p}=0.0001$ ), whereas FRB did not show a significant relationship. The distribution of size classes was not significantly different between $\mathrm{NNPO}$ and $\mathrm{BF}\left(\mathrm{X}^{2}=16.5, \mathrm{p}=0.12\right)$, but they both were significantly different from BFR (BFR vs. BF: $\mathrm{X}^{2}=904, \mathrm{p}=0.000001$; BFR vs. NNPO $\left.\mathrm{X}^{2}=775, \mathrm{p}=0.000001\right)$. Individuals of the first five classes $(\mathrm{DBH}<12 \mathrm{~cm})$ and last two size classes $(\mathrm{DBH}>40 \mathrm{~cm})$ were found in similar proportions in NNPO and BF; individuals of the five intermediate classes were not found. Individuals of the first two classes $(\mathrm{DBH}<3 \mathrm{~cm})$ were found only in BFR (Fig. 3).

The model of spatial distribution of $A$. perutilis showed that suitable habitat for this tree species (areas inside the fragments with a probability of finding A. perutilis greater than 0.7 ) is less than half of the current

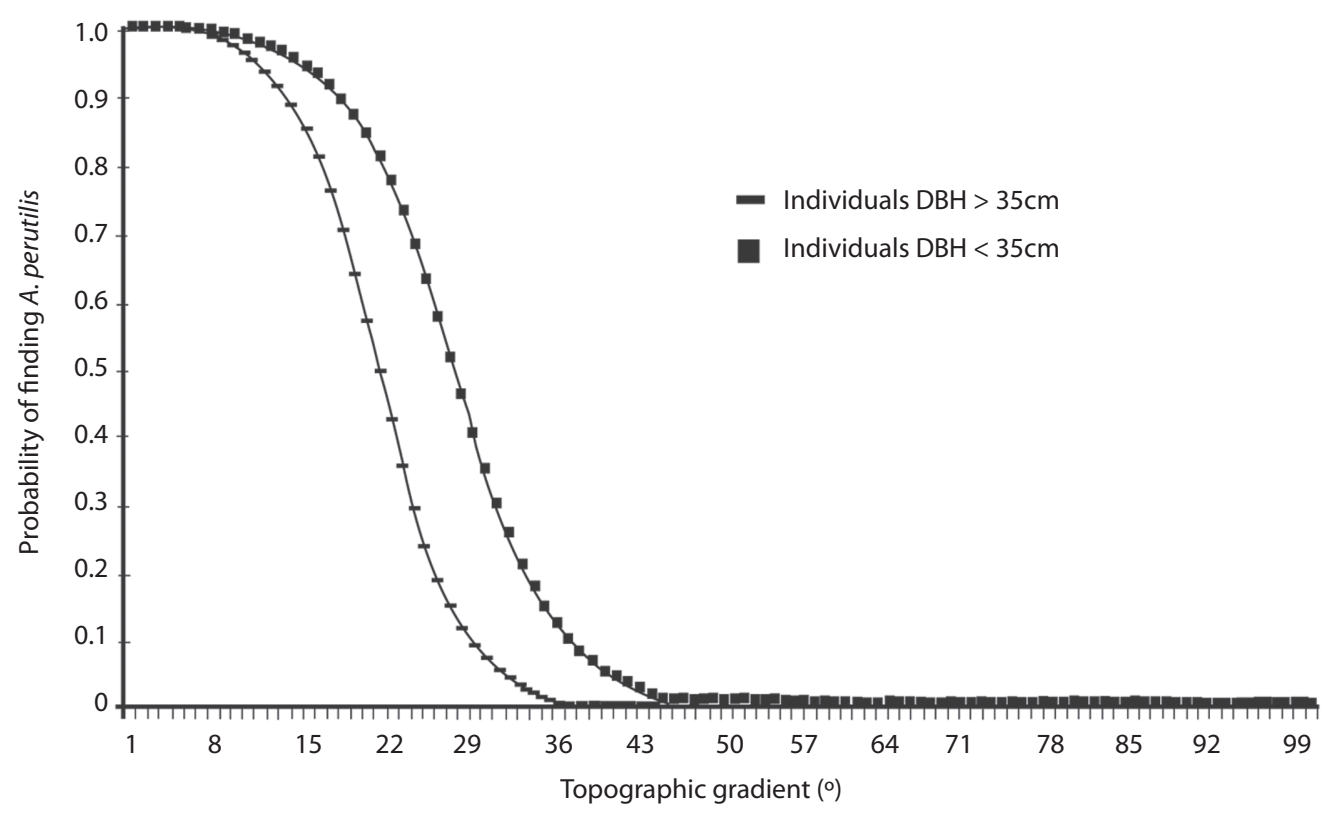

Fig. 2. Probability $(P)$ of finding Aniba perutilis across the topographic gradient. 


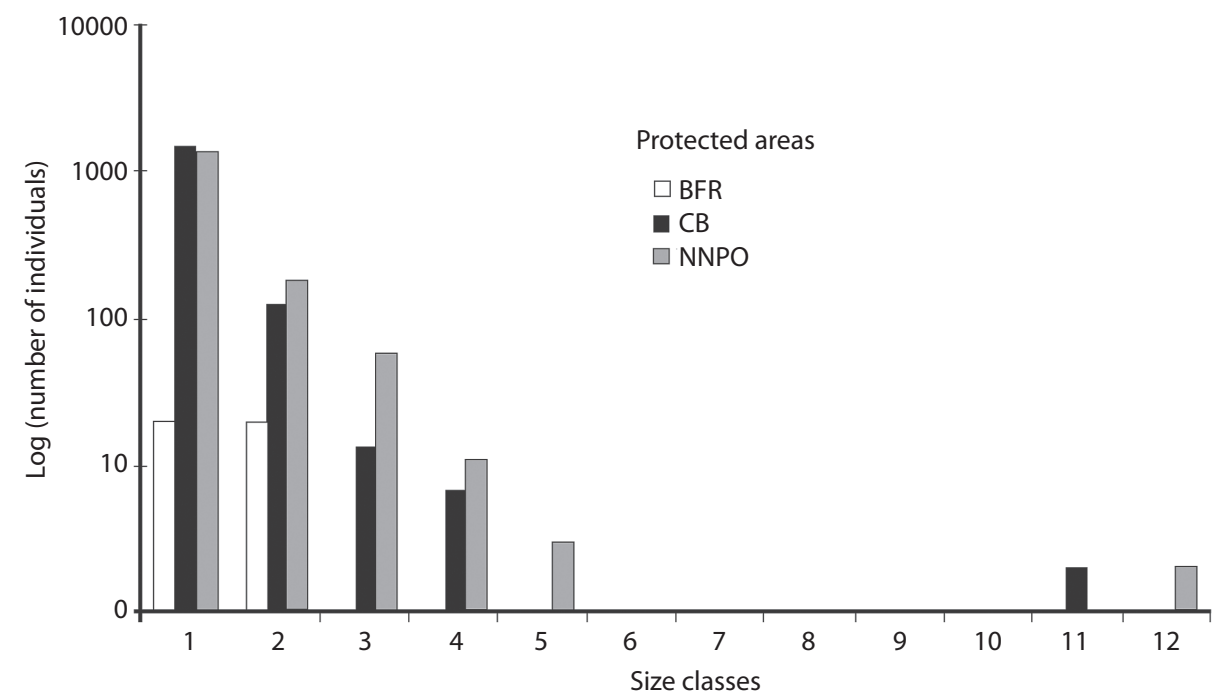

Fig. 3. Size class structure of Aniba perutilis in three protected areas of the central Andes of Colombia: Canyon of the Barbas River (CB), Bremen Forest Reserve (BFR), and National Natural Park Otún-Quimbaya (NNPO). See text for size class parameters.

extension of the three protected areas combined, corresponding to $69 \%, 52 \%$, and $47 \%$ of Andean forest covers of BFR, CB and NNPO, respectively (Table 1; Fig. 4). This result was expected given that ridges and hillsides with gentle topography and Andean forest cover (suitable habitat for A. perutilis) are uncommon in the area.

\section{DISCUSSION}

Species distribution models have been widely used at large regional scales $(1: 100000$ to $1: 500000)$ to predict the potential distribution of tree species based on presence only data (i.e., museum specimens), climatic variables, altitude, and soil type (Montiel 2008, Phillips

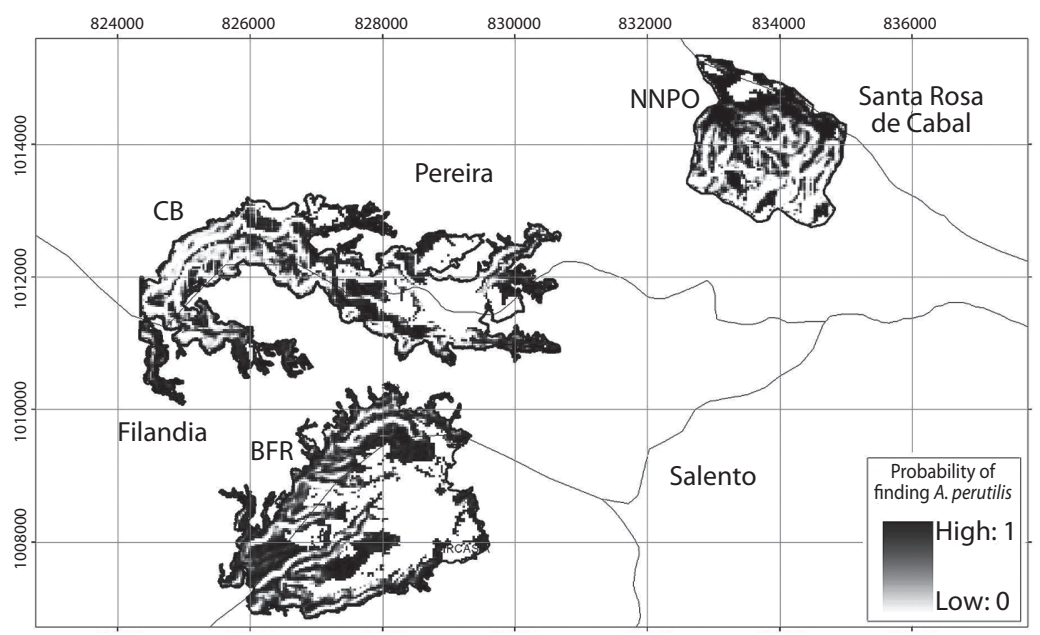

Fig. 4. Spatial distribution model of Aniba perutilis in three protected areas of the central Andes of Colombia: Canyon of the Barbas River (CB), Bremen Forest Reserve (BFR), and National Natural Park Otún-Quimbaya (NNPO). The grid is in meters according to WGS 84 Datum and UTM projection (scale 1:10 000). 


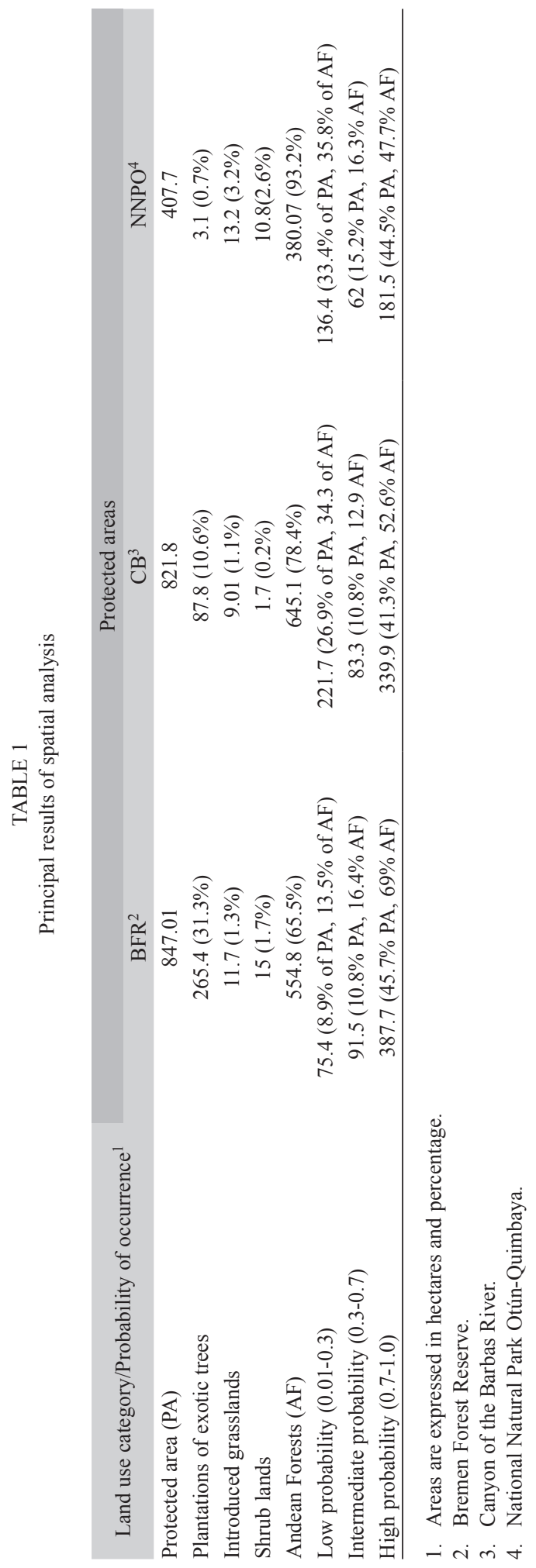

\& Dudík 2008, Soria-Auzaa et al. 2010). Our study predicted the spatial distribution of $A$. perutilis at a fine local scale (1:10 000), based on presence/absence data as well as topographic variables measured in situ. This hierarchical approach allowed us to integrate information from different spatial scales to show how topographic heterogeneity at a very fine scale affects the distribution of $A$. perutilis in a local scale inside the studied forest fragments. Our analysis reveals that the available habitat for A. perutilis is significantly smaller than the extension of the fragment and much smaller than the extension of the currently protected areas. Our results have important implications for the conservation of $A$. perutilis, and likely for other threatened Andean tree species, if they are similarly restricted in distribution by topographic heterogeneity.

A spatial distribution limited by topographic heterogeneity at a local scale, such as that of $A$. perutilis, suggests preference or susceptibility to particular soil conditions, such as moisture (Ohsawa \& Ozaki 1992, Wenny 2000, Kubota et al. 2004). The studied populations of $A$. perutilis showed a strong preference for ridges and slope habitats with slope angles lower than $36^{\circ}$. Despite the high precipitation of the studied areas (mean annual rainfall: $2870 \mathrm{~mm}$ ), seedlings of $A$. perutilis occurred in soils that seemed relatively drier than those in the valleys, where we found no seedlings of this species. Thus, seedlings might be susceptible to excessive moisture as previously suggested for other tropical tree species (Matelson et al. 1995, Clark et al. 1998, Oliveira et al. 1998, Harms et al. 2001, Kubota et al. 2004). Another factor that could also influence the spatial distribution of $A$. perutilis in the studied areas is soil stability (Gale 2000). Soils at high gradients are structurally unstable and plants are more susceptible to fall to the ground due to height, weight, and strong winds. Aniba perutilis trees do not have morphological adaptations for growth in steep areas, such as buttress roots or tabular roots that provide extra anchorage and support. Given the preference of $A$. perutilis for areas with moderate 
gradient and the high topographic gradient that characterized the great majority of the land cover on each forest fragment, it is clear that most of the original habitat suitable for this species, the areas outside the forest fragments, has been transformed.

A population structure with a small number of individuals in several intermediate reproductive size classes, such as that of $A$. perutilis, suggests a gap in the successful reproduction of this species (Harper \& White 1974, Roff 1992, Stearns 1992, Akçakaya et al. 1999). This may have been caused by the absence or low presence of reproductive trees as a consequence of selective extraction, which occurred 50 or 60 years ago, according to local informants. Aniba perutilis was one of the most common trees locally extracted for lumber, especially individuals with DBH $>40 \mathrm{~cm}$. Because selective extraction of $A$. perutilis abruptly decreased about 40 years ago, the few large individuals currently present are those that, scaped harvesting; they could not be used because they did not have a suitable diameter at the time, or for some other reasons. It also suggests that those are the progenitors of most of the current seedlings. Although the breeding system of $A$. perutilis is unknown, it is probable that current populations of $A$. perutilis have some levels of endogamy because the progenitors are few and sparse.

\section{ACKNOWLEDGMENTS}

We thank S. Giraldo, P. Garnica, J. Alzate and L.J. Rojas Valencia for their outstanding logistical support during the field work, and W. Vargas for assistance in plant identification; Amy Comfort de Gonzalez, James Ackerman, Jonathan Koch, and anonymous reviewers for their considerable input, insightful comments and suggestions that improved this work. We would like to thank UMATA of Filandia, Quindio. Support from the Instituto Alexander von Humboldt, Colombia, to the senior author to conduct field study is greatly appreciated. Partial support to V.H.G. was provided by the Department of Biological Sciences, Southwestern Oklahoma State University.

\section{RESUMEN}

La topografía es un factor que puede afectar considerablemente la diversidad y la distribución de las especies de árboles tropicales. Aniba perutilis, una especie de árbol maderable vulnerable a la extinción, está ampliamente distribuida en fragmentos de bosques andinos, especialmente en aquellos con topografía altamente variable. A partir de trabajo de campo y análisis de regresión logística, estudiamos la estructura de la población y los efectos de la topografía sobre la distribución espacial de este árbol en tres fragmentos de bosque en la cordillera central de Colombia que actualmente se encuentran protegidos. Los individuos de $A$. perutilis se encontraron principalmente en los filos de montaña y colinas con gradientes topográficos suaves; no se encontraron individuos en los valles. A partir de un modelo de distribución de especies usando datos de presencia/ausencia, mostramos que el hábitat disponible para $A$. perutilis es considerablemente más pequeño que la extensión de los fragmentos y mucho más reducido que la extensión actual de las áreas protegidas. Nuestros resultados tienen implicaciones importantes para la conservación de $A$. perutilis y probablemente otras especies de árboles andinos amenazados, los cuales pueden estar restringidos de forma similar debido a la variabilidad topográfica local.

Palabras clave: biología de la conservación, fragmentos de bosque, regresión logística, modelos de distribución de especies, estructura poblacional.

\section{REFERENCES}

Akçakaya, H.R., M.A. Burgman \& L.R. Ginzburg. 1999. Applied Population Ecology. Sinauer Associates, Sunderland, Massachusetts, USA.

Alzate, N. 1987. La influencia del Guácharo (Steatornis caripensis) en la germinación de varias especies forestales y en la regeneración del Comino (Aniba perutilis Hemsley) en la región de Río Claro (Antioquia). Trabajo de grado, Universidad Nacional de Colombia, Medellín, Colombia.

Bernal, H.Y. 1994. Especies Vegetales Promisorias de los países del Convenio Andrés Bello, Tomo X. Guadalupe, Bogotá, Colombia.

Cabrera, E., D.M. Vargas, G. Galindo, M.C. García, M.F. Ordóñez, L.K. Vergara, A.M. Pacheco, J.C. Rubiano \& P. Giraldo. 2011. Memoria Técnica de la cuantificación de la deforestación histórica nacional: escalas gruesa y fina. Instituto de Hidrología, Meteorología y Estudios Ambientales -IDEAM, Bogotá, Colombia.

Clark, D.B., D.A. Clark \& J. Read. 1998. Edaphic variation and mesoscale distribution of tree species in a neotropical rain forest. J. Ecol. 86: 101-112. 
Cuatrecasas, J. 1958. Aspectos de la vegetación natural de Colombia. Rev. Acad. Colomb. Cienc. Exactas Fís. Nat. 10: 221-268.

Gale, N. 2000. The relationship between canopy gaps and topography in a western Ecuadorian rain forest. Biotropica 2000: 653-661.

Harms, K., R. Condit, S.P. Hubbell \& R.B. Foster. 2001. Habitat associations of trees and shrubs in a 50-ha Neotropical forest plot. J. Ecol. 89: 947-959.

Harper, J. \& J. White. 1974. The demography of plants. Annu. Rev. Ecol. Syst. 5: 419-463.

Holdridge, L.R. 1947. Determination of world plant formations from simple climatic data. Science 105: 367-368.

Kattan, G.H., P. Franco, V. Rojas \& G. Morales. 2004. Biological diversification in a complex region: a spatial analysis of faunistic diversity and biogeography of the Andes of Colombia. J. Biogeogr. 31: 1829-1839.

Kubota, Y., H. Murata \& K. Kikuzawa. 2004. Effects of topographic heterogeneity on tree species richness and stand dynamics in a subtropical forest in Okinawa Island, southern Japan. J. Ecol. 92: 230-240.

Lichstein, J.W., T.R. Simons, S.A. Shriners \& K.E. Franzreb. 2002. Spatial autocorrelation and autoregressive models in ecology. Ecol. Monogr. 2: 445-463.

Maidment, D.R. 2002. Arc Hydro: GIS for Water Resources. ESRI, Redlands, California, USA.

Matelson, T., N.M. Nadkarni \& R. Solano. 1995. Tree damage and annual mortality in a montane forest in Monteverde, Costa Rica. Biotropica 27: 441-447.

Montiel, O.M. 2008. Predicting species distributions from herbarium collections: does climate bias in collection sampling influence model outcomes? J. Biogeogr. 35: $105-116$

Ohsawa, M. \& K. Ozaki. 1992. Hierarchical analysis of vegetation/environmental patters for East Asian extra-tropical evergreen broad-leaved forest. Jpn. J. Biometeorol. 29:93-103.

Oliveira, A.T., N. Curi, A.E. Vilela \& D.A. Carvalho. 1998. Effects of canopy gaps, topography and soils on the distribution of woody species in a central Brazilian deciduous dry forest. Biotropica 30: 362-375.

Oliveira-Filho, A.T., A.E. Vilela, D.A. Carvalho \& M.L. Gavilanes. 1994. Effects of soils and topography on the distribution of tree species in a tropical riverine forest in south-eastern Brazil. J. Trop. Ecol. 10: 483-508.

Phillips, S.T. \& M. Dudík. 2008. Modeling of species distributions with Maxent: new extensions and a comprehensive evaluation. Ecography 31: 161-175.

PNNC (Parques Nacionales Naturales de Colombia). 2007. Plan de manejo 2007 - 2011 santuario de fauna y flora Otún-Quimbaya. Parques Nacionales Naturales de Colombia, Dirección Territorial Noroccidente, Medellín, Colombia.

PRVCAB (Programa de Recursos Vegetales del Convenio Andrés Bello). 1994. Especies Vegetales Promisorias de los países del Convenio Andrés Bello, Tomo X. Guadalupe, Bogotá, Colombia.

Roff, A.R. 1992. The evolution of life histories. Chapman \& Hall, New York, USA.

Soria-Auzaa, R.W., M. Kesslerc, K. Bachd, P.M. BarajasBarbosa, M. Lehnertf, S.K. Herzogb \& J. Böhnerg. 2010. Impact of the quality of climate models for modelling species occurrences in countries with poor climatic documentation: a case study from Bolivia. Ecol. Model. 221: 1221-1229.

Stearns, S.C. 1992. The Evolution of Life Histories. Oxford University, New York, USA.

Sturges, H.A. 1926. The choice of a class interval. J. Amer. Statist. Assoc. 21: 65-66.

UICN (Unión Internacional para la Conservación de la Naturaleza). 2001. Categorías y criterios de la lista roja de la UICN: Comisión de Supervivencia de Especies de la UICN. UICN Gland, Suiza y Cambridge, Reino Unido.

Vargas, W.G. 2002. Guía ilustrada de las plantas de las montañas del Quindío y los andes centrales. Universidad de Caldas, Manizales, Caldas, Colombia.

Wenny, D.G. 2000. Seed dispersal, seed predation, and seedling recruitment of a neotropical montane tree. Ecol. Monogr. 70: 331-351. 
